\title{
The Commission: Boxed In and Constrained, but still an Engine of Integration
}

Stefan Becker, Michael Bauer, Sara Connolly and Hussein Kassim

In the debate about the impact of the Eurozone crisis on the EU's institutional balance, antagonists have often argued past each other. Supporters of the new intergovernmentalism contend that the European Council has supplanted the European Commission in policy leadership, while scholars who hold that the EU executive has been a winner of the crisis highlight the new management functions it has acquired. This article argues, first, that an accurate assessment of the institutional balance requires a more global evaluation of the Commission, acknowledging external and internal dynamics. Second, it contends that the Eurozone crisis did not cause a Commission retreat. Rather, the crisis accelerated a process already underway that finds its origins in a different dynamic: the presidentialization of policy control undertaken by Commission President Barroso. The adoption of fewer legislative proposals by the Commission during the crisis was due to the ability and choice of a strong president to focus the attention of the institution on crisis-related areas of policy, not the displacement of the institution by the European Council. The broader lesson is that rather than marking a further step in the decline of the Commission, the crisis reveals how the centralization of power within the institution and its expanded management duties have enhanced its capacity to take strategic action. The Commission's role as an engine of integration will therefore endure, but in a different guise.

Keywords: European Commission, Economic Governance, Eurozone Crisis, New Intergovernmentalism

\section{Introduction}

At the very moment the Lisbon Treaty entered into force - and thereby brought a decade of constitutional debate in the European Union (EU) to an end - the Eurozone crisis put the new institutional balance to the test. Widely viewed as one of Lisbon's losers, the Commission immediately faced a critical moment that questioned its institutional role (Laffan 2016). The EU's handling of the crisis raised serious questions about the Commission's role in economic governance and EU policy-making in general. 
Although the debate about the Commission's influence over EU policy is as old as European integration itself (e.g. Haas 1958; Lindberg 1965), the focus over the last two decades has been on its apparent decline, challenged by the growing role of the European Council, the empowerment of the European Parliament, and the creation of new regulatory agencies (e.g., Kassim and Menon 2010; Kassim et al. 2013: 131-135). More recently, this argument has been extended by advocates of a 'new intergovernmentalism' who emphasize the proliferation of decision-making processes beyond the Community method, the reluctance of member states to delegate further competences to the 'traditional' supranational institutions, and the emergence of the European Council as the central actor in EU policy-making (Bickerton et al. 2015a). The new intergovernmentalism seeks to 'recast' the role of the Commission and the Court of Justice 'in a new mould', arguing that these institutions are now 'more circumspect about the pursuit of ever closer union' (Bickerton et al. 2015b: 39). In the era of new intergovernmentalism, which began with the Maastricht Treaty, they are 'are no longer the "engines of integration" that they once were' (Bickerton et al. 2015a: 717). Authors writing from this perspective about the crisis depict the Commission as the "little engine that wouldn't' (Hodson 2013). More modestly, Peterson (2015: 207) argues that, despite the trend towards an intergovernmentalist dynamic, the Commission 'mostly gets on with its work', which mainly 'is focused on closer European policy cooperation'. It might even represent 'an oasis of calm within the storm' in the disequilibrium that is the current EU. Becker and Bauer (2014), by contrast, have challenged the view that the Commission's role has been diminished as a result of the crisis and contend, to the contrary, that the Commission emerged stronger with important new managerial tasks in economic governance.

This article argues that the impact of the crisis on the Commission is considerably more complex than is suggested by the current debate and contests key elements of the new intergovernmentalist approach. First, any assessment of the effects of the crisis on the Commission in the institutional balance needs to look beyond either policy-making as highlighted by the new intergovernmentalism or management responsibilities. A more global examination, acknowledging external and internal dynamics, is necessary. The Commission's role as an engine of integration that seeks to provide leadership and impetus for EU policy-making, its own traditional interpretation of its mandate to 'promote the general interest of the Union' (Art. $17 \mathrm{TEU}$ ), needs to be reconsidered. Entrepreneurship, i.e., aiming "to induce authoritative political decisions that would not otherwise occur", by the Commission has long been based on 'favoring more ambitious schemes for further institutional and substantive integration' (Moravcsik 1999, 271). It is now more subtle and versatile. 
Second, although the number of proposals adopted by the Commission - and, correspondingly, the volume of EU legislation - did fall when the Eurozone crisis broke in 2010, the crisis was a catalyst rather than a cause of the decline in legislative proposals. The crisis did not initiate the change, but altered the speed of a process of change that had already been underway for a number of years. Moreover, contrary to claims that the Commission had retreated or been eclipsed by the European Council, analysis shows that far from abandoning the field, the Commission concentrated its attention on aspects of economic governance and provided leadership in areas that pertained directly to the Eurozone crisis.

Third, the explanation for a reduction of the Commission's policy activism is to be found in an intra-organizational process rather than the inter-institutional dynamic highlighted by the new intergovernmentalism. The downward trend in the Commission's decisional outputs was the result of concerted action on the part of its eleventh President, José Manuel Barroso, to strengthen presidential control over the Commission's policy activism, especially during his second term, not displacement of the Commission by the European Council. Indeed, the crisis accelerated the process of presidentialization that had begun during Barroso's first term. Both Barroso after 2010 and Jean-Claude Juncker, his successor, have used the enhanced powers and resources available to the office to take personal control over the Commission agenda and to end the expansionist policy activism that historically characterised the organization. As a result, a new model of Commission intervention has emerged - top-down managed, measured, restrained, and strategic - that contrasts with the unprogrammatic and piecemeal approach of the past.

Drawing on new empirical evidence - two large-scale surveys in the Commission, ${ }^{1}$ interviews with high-level officials, and legislative data from EUR-Lex - to support these contentions, the article proposes a new interpretation of the impact of the crisis on the Commission and a new assessment of the organization's post-crisis position. It contends that the Commission may face increased constraints, but its capacity to legislate, even in controversial areas such as economic governance, is still important. Moreover, its expanded management duties mean new opportunities to provide impetus for EU policy-making. Finally, the emergence of presidentialized leadership has equipped the Commission with a new strategic ability, enabling it to act more programmatically and with greater focus than previously.

\section{The Commission on the Eve of the Crisis}


In order to assess the changes in the role of the Commission during the crisis, it is essential to revisit the point of departure. The Commission had already undergone several transformations by the time the Eurozone crisis unfolded in 2010. This section reviews its condition before the crisis, at the end of 2009 , to provide a benchmark against which to assess subsequent change.

\section{Institutional and Political Environment}

The Commission has historically been an embattled institution (see e.g. Lindberg 1965). Since the early 1990s, however, it had come under particular pressure. Successive treaty changes Maastricht, Amsterdam and Nice - had encroached upon the Commission's institutional position by strengthening the European Parliament, limiting the Commission's power in new EU competences, and delegating regulatory tasks to other executive bodies (Kassim and Menon 2004). Shortly before the crisis, the entry into force of the Lisbon Treaty furthered undermined further its centrality. First, although the European Council already played an influential role in setting the EU's political agenda, the formalization of its position was of practical and symbolic significance. The wording of Article 15 (1) TEU, namely, that the European Council 'shall provide the Union with the necessary impetus for its development and shall define the general political directions', overlaps with the Commission's mission to promote the Union's general interest. As well as acknowledging the European Council's long-standing leadership role, the Lisbon Treaty established a full-time presidency. This strengthened the European Council's capacity by enabling it to develop more focused working methods (Puetter 2012). It has thus become an even stronger challenger for the Commission in setting the agenda and formulating answers to strategic problems. Second, the Lisbon Treaty further empowered the European Parliament by the expansion of co-decision. Although the Commission kept its sole right of initiative in most policy areas and remained the crucial actor for policy formulation, ${ }^{2}$ its role of delivering policy proposals grew more complex due to an additional veto player and a more heterogeneous set of preferences. This made Commission policy entrepreneurship in the classic sense - i.e., formulating and pushing for hard law in the Community method more difficult.

In addition to the Lisbon reforms, the political environment of the pre-crisis years also affected the Commission. Although European integration was never acclaimed by ordinary citizens, European elites were relatively unrestricted when negotiating EU matters. This 'permissive consensus' had all but vanished; political actors now operated under a 'constraining 
dissensus' (Hooghe and Marks 2008: 5). European integration was heavily politicized and closely scrutinized (for a recent account, see Hutter and Grande 2014). Blame games and general complaints about 'Brussels' being too powerful and interventionist were common. Positive views on EU membership among its citizens frequently dipped below the 50 per cent level since Maastricht; and although public opinion fluctuates, such dips had not happened before (for an overview, see Commission 2014a). This growing hostility effectively limited the Commission's ability to propose bold integration proposals, and even modest initiatives often attracted negative responses. Furthermore, enlargement made policy entrepreneurship for the Commission more complicated; by now, it had to accommodate the preferences of 28 member states when developing policy proposals. At the same time, its responsibilities as the guardian of the treaties had expanded in scale, scope and complexity. As a consequence, the Commission's task portfolio had shifted towards management (Bauer 2006; Laffan 1997; Metcalfe 1992; Kassim and Menon 2004, 2010). Finally, some policy fields were by now almost saturated; the main legislative work had been done. The governance of the single market had, for instance, broadly moved from development to management (see also Pelkmans 2016). In general, the Commission was now more concerned with implementation, better regulation and improving the quality of existing legislation than promulgating new laws. The combined effect of the institutional and political environment for the Commission was thus a stronger focus on management rather than policy entrepreneurship.

\section{Internal Organization}

The presidentialization of the Commission was also a key factor in the pre-crisis years. Starting from a low base (Campbell 1983: 181), the Commission presidency has become increasingly powerful since the 1990s and especially since 2004 (Kassim 2012; Kassim et al. 2016). Acutely aware of growing Euroscepticism, wariness if not hostility about intervention from 'Brussels' on the part of national capitals, and seeking to combat the perception of the Commission as a remote bureaucracy driven by a relentless desire to regulate 'every matter under the sun', Barroso used the constitutional powers available to the office to strengthen the Commission Presidency as a means to control policy activism within the institution. He believed that the Commission could only succeed if it concentrated on issues where the EU could demonstrably add value, showed greater sensitivity to member governments, and made more use of options other than 'hard' law (Kurpas et al. 2008). Strengthening the Commission Presidency, he used the enhanced resources of the office to promote a more discriminate, dis- 
ciplined and measured approach to policy, established quality control systems, and implemented a better regulation agenda. He also took personal charge of certain policy areas, as well as putting his name to key initiatives.

Historically, the Commission had been a fragmented institution, where power was widely dispersed within the College and between the services (Coombes 1970; Kassim et al. 2013: chs 6, 7). In the absence of a central capacity to orchestrate or promote a coherent or unified programme, individual Commissioners and policy Directorates General had considerable autonomy to pursue their own policy agenda. Since the 1990s and especially since 2004, however, the powers of the Commission Presidency have been significantly enhanced. Not only is the policy leadership of the Commission President now unchallenged, but the incumbent has been able to bring policy activism within the Commission under control. Strong presidentialism is no longer an exception that is based on personal qualities, such as in the case of Delors, but underpinned by formal organization.

This presidentialization can be explained in terms of three main factors. The first is the differentiation of the Commission President from other members of the College. Beginning with the Treaty of European Union, which provided for a separate selection procedure for the Commission President, successive treaties have steadily strengthened the incumbent's personal mandate. In terms of policy leadership, the primacy of the Commission President was first established by the Treaty of Amsterdam. Successive treaties also granted the Commission President powers to appoint other Commissioners, decide on their portfolios, and to dismiss them.

Second, new administrative capacities, established within the Secretariat General as part of the Kinnock reforms that were enacted under the Prodi Commission in response to the crisis that led to the resignation of the Santer Commission, were an important step in developing an administrative platform at the centre of the institution enabling policy coordination and oversight. The most important was Strategic Planning and Programming (SPP), a system of priority-setting and resource allocation. The introduction of impact assessment procedures was also significant.

Political entrepreneurship on the part of Barroso is a third factor. Barroso mobilized the formal powers granted by the treaties both to reaffirm the pre-eminence of the Commission Presidency and to extend the procedural and administrative resources of the office, with the aim of establishing detailed presidential control over the College and the wider organiza- 
tion (Kassim et a.l 2016, Kurpas et al. 2008). His transformation of the Secretariat General, historically, the guardian of collegiality and the representative of the Commission administration to the political level, into a personal service of the Commission Presidency was a key element. Since the Secretariat General is the Commission's central coordinating body and process manager, its conversion dramatically extended the Commission President's reach into the administration and grip over policy. Moreover, since the Secretariat General was the locus of SPP, the Commission President gained important control over policy coordination and internal gatekeeping.

Survey responses and data from interviews with Commissioners, cabinet members and managers as part of 'The European Commission in Question', carried out in 2008 and 2009 at the end of Barroso I (and reported in Kassim et al. 2013: 6) testify both to the increased power of the Commission President and to his control over the policy agenda. Three of the five Commissioners interviewed for that project characterised Barroso I as presidential rather than collegial. Giving their answers to the online survey distributed to policy officers and members of cabinet in 2008 as part of 'The European Commission in Question', respondents rated Barroso as strong on 'setting a policy agenda' and 'managing the house'. These views were expressed especially strongly by cabinet members and senior managers. In interviews, senior managers in particular testified that Barroso closely controlled the policy agenda at all levels of the policy process. Cabinet members highlighted how in meetings of 'special chefs', the President's chef de cabinet had shaped, delayed or effectively vetoed policy proposals. They noted that Barroso kept a much tighter rein on the Commission's policy programme than his immediate predecessors (see Kassim et al. 2013: ch 6).

It would be surprising if such a dramatic reorientation had been welcomed positively by staff. Most theoretical perspectives on bureaucratic change, including sociological institutionalism and historical institutionalism - public choice accounts are an exception - suggest that bureaucrats are conservative and wary about, if not hostile, to administrative reform (Kassim 2008). In the case of the Commission, concentration of power in the hands of the President was at odds with the principle and the practice of collegiality (Dimitrakopoulos 2008) and the assertion of presidential control over policy was likely to offend not only other members of the College, but Directors General who had been powerful and important policymaking figures (Coombes 1970; Kassim et al. 2016). Coming immediately after the Kinnock reforms, which had sought to give the Commission a stronger organizational steering capacity and to strengthen management, but on which staff were divided (Kassim 2008; Kassim et al. 
2003: ch 8), the presidentialisation of policy-making authority was likely to be interpreted as a further step away from the Commission's traditional mission.

Evidence from 'The European Commission in Question' shows that there was indeed strong ambivalence among Commission staff about both presidentialisation and the emergence of a more interventionist Secretariat General that had accompanied it (Kassim et al. 2013: chs 6,7). They were also divided on whether coordination from the centre was a good thing and on the new emphasis on management. Although recognizing that the introduction of processes such as SPP had been intended to make the overall administration more systematic, effective and accountable, many doubted its effectiveness and value. Moreover, for many officials, 'managerialism' ran counter to the Commission's culture, which prized policy formulation far above policy management and implementation. Although 49 per cent of respondents to the online survey administered as part of the 'European Commission in Question' agreed or strongly agreed with the proposition that 'The Commission is increasingly more involved in policy management and coordination, and less in policy conception or initiation', there was little evidence that there had been an accompanying change in the Commission's administrative culture. In the same survey fully 79 per cent of respondents disagreed with the proposition, 'The Commission should focus primarily on managing existing policies rather than developing new ones'. The 38 per cent who merely disagreed were outnumbered - albeit marginally - by the 41 per cent who strongly disagreed.

\section{Legislative Activity}

The institutional and organizational transformations of the Commission preceding the crisis are clearly reflected in its output of the time. In line with his ambitions, Barroso succeeded in shifting the Commission towards a more programmatic, disciplined and sensitive approach. It has not become less active but more and more diversified in the use of legislative instruments and increasingly opting for less intrusive measures. Analysis of data from EUR-Lex reveals that the EU executive reduced the number of hard law proposals after a peak of legislative activity in the late 1980s and early 1990s (see also Kurpas et al. 2008). In 2009, on the eve of the crisis, the Commission issued proposals for 145 regulations and 30 directives. Exactly 20 years earlier, it proposed 418 regulations and 133 directives. The numbers thus dropped by 65 per cent and 77 per cent respectively. During the same period, the number of decision pro- 
posals increased by 88 per cent, from 140 to 263 . This attenuates the overall decrease in hard law proposals, but it still amounts to 37 per cent.

At the same time, the Commission produced an increasing amount of soft law. In 1989, communications and reports added up to a total of 100; in 2009, there were already 360 such documents. The ratio of hard law to these forms of soft law thus changed from 1/0.16 to 1/0.82. Annual numbers are subject to some fluctuation, but a comparison of averages of preparatory acts in five-year intervals from 1985 to 2009, broadly representing Commission terms, yields similar results (Table 1). The overall output thus remained fairly constant over the years, but its composition changed considerably.

\section{TABLE 1}

ANNUAL AVERAGE OF COMMISSION PREPARATORY ACTS BY TYPE IN FIVE-YEAR INTERVALS

\begin{tabular}{ccccccc}
\hline & Regulations & Directives & Decisions & Communications & Reports & Total \\
\hline $1985-1989$ & 456 & 106 & 106 & 58 & 67 & 793 \\
$1990-1994$ & 392 & 122 & 140 & 54 & 56 & 764 \\
$1995-1999$ & 262 & 103 & 201 & 104 & 115 & 785 \\
$2000-2004$ & 227 & 82 & 238 & 167 & 115 & 829 \\
$2005-2009$ & 190 & 69 & 211 & 231 & 120 & 821 \\
\hline
\end{tabular}

Notes: Rounded numbers.

Source: EUR-Lex. Search query: Preparatory acts, date of document, excludes corrigenda.

There have also been significant shifts between policy fields. ${ }^{3}$ These can again be illustrated by comparing the numbers for 1989 and 2009. Agriculture and fisheries, previously hot spots of Commission activity, have witnessed a decrease of roughly two-thirds in preparatory acts, from 301 to 91 . The progress in the integration of the single market led to an over 90 per cent drop in the field of customs, from 112 to 19 . The most significant increase in output is related to the gradual integration of justice and home affairs in the new millennium. Previously not a concern for EU action, the Commission issued 82 preparatory acts in this field in 2009. The field of environment, customers and health has also experienced strong growth. Respective Commission output more than doubled, arriving at over 100 preparatory acts per year shortly before the crisis. Furthermore, outputs in general, financial and institutional matters as well as in economic and monetary policy, starting with minimal Commission activity, more than tripled, arriving at 59 and 45 preparatory acts respectively. Finally, a moderate increase of 20 per cent can be observed in the field of external relations, i.e., common commercial policy 
and bilateral agreements. By 2009, the Commission therefore proved to be an institution with a broad sphere of action. This diversity can also be interpreted as a lack of focus: of all internal policy fields, not a single one accounted for more than 10 per cent of all preparatory acts.

In sum, on the eve of the crisis the Commission was already in a process of transformation. Institutionally, the Lisbon Treaty had increased the powers of the European Council and the European Parliament, while politically the Commission faced an increasingly sceptical climate. The response of the Commission under Barroso's first term had been to enact a major departure from previous practice. Building on the expanded formal prerogatives to further strengthen the office, Barroso used the political, procedural and administrative resources of the Commission Presidency to take a more disciplined, limited and sensitive approach to policy-making. In particular, there was a marked shift from hard to soft legislation. A substantial focus had, however, not yet materialized.

\section{The Commission and the Crisis}

When the Eurozone crisis unfolded in 2010, it threw the EU into political and institutional turmoil. In regard to the Commission, however, the crisis mainly served as a catalyst that reinforced trends in its institutional and political environment, internal organization and legislative activity.

\section{Institutional and Political Environment}

In line with its new status accorded by the Lisbon Treaty, the European Council emerged as the main venue for debating how the EU should respond to the Eurozone crisis (Puetter 2012). Although it has no legislative function under Article $15 \mathrm{TEU}$, in what might be interpreted as a deliberate move to pre-empt discussions of strong supranational solutions, the European Council not only defined the broad strokes of the crisis response but also put forward policy details. As Fabbrini (2013: 1011) argues, at the onset of the crisis 'the EU intergovernmental constitution enjoyed the support of a powerful constellation of political leaders and public opinions'. Indeed, important national leaders, such as Nicolas Sarkozy and Angela Merkel, quickly made it known that they preferred intergovernmental decision-making and outcomes to supranational alternatives, which included empowerments of the Commission (see also Dehousse 2015). This sentiment also corresponded with public opinion. Trust in the Commis- 
sion among EU citizens dropped by ten percentage points in the first two years of the crisis, from 46 per cent trusting the institution in the fall 2009 to 36 per cent in the fall 2011 (Commission 2013: 50-70). Talks of a new 'Union method' as an alternative to the 'Community method', Commission proposals that went nowhere, such as the Eurobonds (Hodson 2013), and the first institutional outcomes - i.e., lending facilities outside the EU's legal system - all highlight the intergovernmental character of early crisis management.

However, the institutional responses to the crisis have actually strengthened the Commission (Bauer and Becker 2014). ${ }^{4}$ The Commission's involvement in economic policy surveillance is now broader and deeper. As a result of the 'six-pack' legislation, the Commission became responsible for monitoring the overall public debt and developments in national expenditure. Its assessments and recommendations also carry additional weight due to 'reversed qualified majority' voting for fines and sanctions. The Commission is also responsible for managing the new Macroeconomic Imbalance Procedure, in which it is able to conduct quantitative and qualitative analyses of national trade balances. Under the 'two-pack' legislation, the Commission is further entrusted with assessing - in an advisory capacity - the conformity of draft national budgets with EU rules, while as part of the intergovernmental Fiscal Compact, aimed at further strengthening fiscal discipline and intensifying surveillance, the Commission has a role in developing policy principles and monitoring compliance.

The coordination procedures for national policies in areas of common interest, including social security and employment, have also been upgraded during the crisis. Both the Europe 2020 process, the successor of the Lisbon Strategy, and the Euro Plus Pact, which was adopted in 2011 by the Eurozone members and six other states to promote competitiveness, employment and sustainable public debt, have broadened the Commission's responsibilities. Its role is to gather and synthesise information and recommend paths of action. Finally, even the intergovernmental arrangements in the field of financial stability support involve the Commission in a number of capacities. Along with the European Central Bank, the Commission assesses the financing needs of applicants and subsequently proposes decisions on granting assistance. As part of the troika, which also features the European Central Bank and the International Monetary Fund, the Commission then negotiates conditionality agreements and monitors compliance afterwards.

The crisis has thus reinforced, at least in economic governance, the Commission's shift from policy entrepreneurship to management. Rather than weakening its position, however, this has strengthened the Commission, as the delegated tasks are not purely administra- 
tive matters. On the contrary, these coordination, negotiation and monitoring duties come with some discretion in highly political matters. The crisis and its institutional outcomes have therefore created new opportunities for the Commission to influence policy-making in the EU, even if they are less obvious than the classic entrepreneurship through hard law proposals.

\section{Internal Organization}

The crisis served to reinforce presidential leadership, first under Barroso II and second with the election of Jean-Claude Juncker. At the outset of his second term in 2010, which followed the entry into force of the Lisbon Treaty the preceding year, Barroso reinforced the Commission President's leadership role. Symbolising his pursuit of his aim of a more programmatic approach to policy, Barroso introduced a State of Union speech, to be given by the Commission President each September - the first was delivered in 2010 - that would set the main policy priorities not only of the Commission, but of the EU more generally, for the coming year. The speech would inform the policy agenda set out in the Commission's annual work programme. Moreover, Barroso took the decision that in the prevailing climate of austerity the Commission should focus its attention on crisis-related areas of policy only. Intervention in other areas would be seen as an unnecessary distraction. In the words of a senior manager in the Secretariat General: 'the legislative activity of the Commission was put on the backburner or in the freezer for a while'. ${ }^{5}$

Evidence from 'European Commission: Facing the Future' attests to the presidentialism of Barroso II. When asked their opinion on the propositions, 'Some people argue that the College under the current President is a presidential body; others that it is collegial', all eight members of the Commission in the sample expressed the view that the Commission was presidential. There was also consensus among the eight that College discussion was limited. Similarly, in face-to-face interviews conducted in 2014, 75 per cent of managers (total $n=110$ ), 80 per cent of Directors General (total $n=18$ ) and 92 per cent of cabinet members (total $n=17$ ) characterized the Barroso Commission as 'more presidential' rather than 'more collegial'.

When he succeeded Barroso, Juncker further reinforced presidentialization. The Spitzenkandidaten process by which he was elected Commission President gave Juncker a unique claim to personal authority (Christiansen 2016). Having won the EPP's primary contest, he became the party's official candidate in the 2014 elections to the European Parliament. Then, following his nomination by the European Council and his election by a majority 
of MEPs in the new Parliament, Juncker could claim that he had a mandate to put into effect the policy programme on which he had campaigned. That platform identified a number of policy priorities, but Juncker also argued that in the post-crisis climate the Commission urgently needed to deliver. It was in this context that as nominee Commission President Juncker spoke of the 'last chance Commission'.

The radical restructuring of the College undertaken by Juncker was designed not only to institutionalize the pre-eminence of the Commission President, but to address a number of weaknesses, old and new, in the Commission. ${ }^{6}$ A first aim was to ensure that Commissioners were collectively mobilised behind the implementation of his policy programme. Departing from tradition, Juncker looked to recruit seven Vice Presidents. A largely honorary title in previous Commissions, ${ }^{7}$ Juncker wanted Vice Presidents to play a 'hands on' role either in coordinating designated policy groups of portfolio Commissioners or managing institutionwide functions. The creation of a tier of Vice Presidents, subject to the authority of the Commission President, was a strategy intended to establish shared leadership and responsibility to 'ensure a dynamic interaction of all Members of the College' (Commission 2014b).

Second, a complaint of the leadership during the Barroso era, particularly in the second term, had been that individual Commissioners often 'went missing' at moments of stress. ${ }^{8}$ Appointing senior politicians - former Prime Ministers, deputy Prime Ministers, and Foreign or Finance Ministers - to the position of Vice President was intended ensure that political responsibility could spread among a team of experienced individuals, used to dealing with the media. Third, the restructuring was intended to ensure implementation of the Commission's policy programme. Juncker had made clear that only policy proposals relating to his 'ten priorities' would be adopted. Allowing Vice Presidents alone the right to submit agenda items for discussion at meetings of the College created a mechanism for policing this rule.

A final aim of the new structure was to give the Commission the powerful political leadership it had lacked for much of its history and especially to overcome its administrative fragmentation. In addition to the lack of shared purpose among Commissioners (Coombes 1970), the asymmetry between career politicians and permanent civil servants had been particularly sharp in the Commission's case. The new organization of the College was intended to prevent 'divide and rule' strategies on the part of Director Generals and to ensure that, faced by a united political leadership, '[t]he directors-general, all highly competent, have to obey their Commissioners and not the other way round' (Juncker 2014). As Juncker explained: 'They will work together in a spirit of collegiality and mutual dependence. I want to 
overcome silo-mentalities and introduce a new collaborative way of working in areas where Europe can really make a difference' (Commission 2014b).

This new model was radical, because it appeared to depart from the convention that all Commissioners are equal. However, Juncker denied this was the case: 'In the new Commission, there are no first or second-class Commissioners - there are team leaders and team players.' Second, although groups of Commissioners were nothing new - Hallstein had used them in the first College, as had Prodi and Barroso in the more recent past - the idea of flexible, fluid and overlapping teams was an innovation. Third, it raised issues of command and accountability. Since Vice Presidents would not be responsible for particular services, the new structure appeared to break the link between the Commissioner and his or her department. Interviews conducted with senior officeholders in the Juncker Commission emphasize the topdown character of decision making, which is even more personal and presidential than under Barroso. Proposals are rigorously screened first by the Vice Presidents, then by First Vice President Timmermans, and the catalogue, to which items not on the Commission work program were added, has been all but abolished. In reporting on its first hundred days, the Juncker Commission proudly plotted Commission actions in terms of the implementation of the President's ten priorities.

\section{Legislative Activity}

The crisis years brought further shifts in legislative activity by the Commission. Existing trends continued and partly accelerated. Overall, the output of the Commission fell during Barroso II, even compared to Barroso I. However, the reduction was only indirectly due to the crisis and more an effect of the mechanisms introduced to increase the Commission President's control over policy-making. The role played by the Secretariat General and procedures such as impact assessment and the advance notice required by SPP to allow entry to the Commission work programme were effective in the development of a more programmatic approach and to dampening policy activism.

The pattern of sectoral differentiation between 2010 and 2014, however, reflects the decision of Commission President Barroso to focus on crisis-related areas. Economic governance is front and centre. Excluding external relations, the plurality of preparatory acts (70) issued by the Commission in 2014 was in the field of 'Economic and Monetary Policy and Free Movement of Capital'. In the three years before the crisis, from 2007-2009, this category 
only ranked tenth in the list of the most lively internal policy fields. Much of this increase can be attributed to the Commission's strengthened role in the European Semester, in particular the reinforced surveillance of macroeconomic policy and the new standing of country-specific recommendations since 2012. But even before, the Commission proved quite active in this field, especially in administering balance-of-payments assistance to Hungary, Latvia and Romania. It comes as no surprise then that in the period from 2010 to 2014, 'Economic and Monetary policy and Free Movement of Capital' was the fourth most dynamic field of Commission activity, being closely behind 'General, Financial and Institutional Matters', 'Industrial Policy and Internal Market' and 'Environment, Consumers and Health Protection' (see Table 2). In comparison with the immediate pre-crisis years, it not only surpassed the declining output in agriculture and fisheries, but also the most upcoming field in the first decade of the new millennium, that is justice and home affairs.

TABLE 2

COMmission Preparatory ACts in Ten Most ACtive InTERnAl Policy Fields 2010-2014

\begin{tabular}{lllllllll}
\hline Policy field & $\mathbf{2 0 1 0}$ & $\mathbf{2 0 1 1}$ & $\mathbf{2 0 1 2}$ & $\mathbf{2 0 1 3}$ & $\mathbf{2 0 1 4}$ & $\begin{array}{l}\text { Total } \\
\mathbf{2 0 1 0}-\end{array}$ & $\begin{array}{l}\text { Total } \\
\mathbf{2 0 0 5}-\end{array}$ & $\begin{array}{l}\text { Change } \\
\text { in per cent } \\
\mathbf{2 0 0 9}\end{array}$ \\
General, Financial and Institutional Matters & & & & & & & \\
2014 & 126 & 100 & 51 & 73 & 55 & 405 & 384 & +5 \\
Environment, Consumers and Health Protection & 90 & 88 & 75 & 83 & 43 & 379 & 538 & -30 \\
Industrial Policy and Internal Market & 88 & 106 & 65 & 52 & 46 & 357 & 527 & -32 \\
Economic and Monetary Policy, Free Movement of Capital & 77 & 41 & 71 & 94 & 70 & 353 & 181 & +95 \\
Area of Freedom, Security and Justice & 61 & 77 & 52 & 66 & 54 & 310 & 323 & -4 \\
Freedom of Movement for Workers and Social Policy & 64 & 58 & 50 & 39 & 42 & 253 & 239 & +6 \\
Fisheries & 42 & 42 & 47 & 38 & 45 & 214 & 203 & +5 \\
Transport & 29 & 40 & 37 & 52 & 49 & 207 & 298 & -31 \\
Agriculture & 58 & 46 & 32 & 38 & 24 & 198 & 340 & -42 \\
Taxation & 20 & 24 & 29 & 30 & 21 & 124 & 135 & -8
\end{tabular}

Notes: Percentages rounded. Categories according to directory code.

Source: EUR-Lex. Search query: preparatory acts, date of document, excludes corrigenda.

Furthermore, these numbers only include the Commission's role in financial stability support only in regard to supranational lending facilities, i.e., the balance-of-payments assistance and the European Financial Stabilization Mechanism. The important roles it plays in the intergovernmental facilities (the European Financial Stability Facility and the European Stability Mechanism) - analysing financing needs, negotiating memoranda of understanding and moni- 
toring implementation - are not represented in this data. For the second Greek bailout alone the Commission produced, in liaison with the European Central Bank and the International Monetary Fund, twelve informal documents, including four 300-page reviews. The actual increase of Commission activity in economic governance is therefore even higher. And it was not stopped by the incoming President Juncker's strategy of legislative self-restraint. While this decision applied to all policy fields, economic governance was among the least affected. In fact, roughly half of the 23 new initiatives in the Commission work programme for 2015 were more or less explicitly economic policy issues (European Commission 2015).

This quantitative expansion is accompanied by qualitative assertiveness. Respective evidence can be found in different areas of economic governance. As regards general institutional development, Copeland and James (2014: 12) provide an account of how the outbreak of the crisis has enabled the Commission 'to secure agreement on an important series of reforms which established a new governance architecture of economic surveillance' when steering the discussion on the reform of the Europe 2020 strategy. As was shown earlier, the Commission gained significant competences, when this governance architecture later materialized. It then quickly emerged that, in practice, the Commission followed a clear mission when using its discretion in rule application, showing significant lenience towards member states struggling to meet the new criteria. As Schmidt (2016: XX) argues, the Commission proved 'flexible and accommodating, given that [the member states] were encouraged to find ways to ameliorate their balance sheets while avoiding pro-cyclical measures'. Belgium, France and Italy were the states that most openly benefited from this approach. While the member states are ultimately decisive in these proceedings, it is obvious that the Commission recommendations effectively steer the decision-making phase. In 2015, the incoming Juncker Commission underlined its willingness to further pursue the applied flexibility by issuing a communication (COM/2015/012) on the application of the existing rules in the Stability and Growth Pact. It set out to re-interpret exceptions for states implementing structural reforms. This document and the preceding lenience clearly run counter the preferences of many member states, especially Germany, that preferred stricter adherence to the new rules. Indeed, this development represented 'one of the remarkable aspects of changes introduced in the economic governance of the EU in the wake of the economic and financial crisis' (Dehousse 2015: 2).

Further evidence for Commission assertiveness can be found in its exercise of coordination functions. Schmidt (2016) shows how the Commission slowly changed the direction of 
policy coordination in the Europe 2020 strategy from strictly economic - i.e., subordinating every policy field to fiscal consolidation - to a broader, increasingly social agenda. More broadly, the Commission has used the reformed architecture of the European Semester to bolster the effect of country-specific recommendations, which are in principle not binding, by symbolically coupling them with its monitoring results in macroeconomic surveillance. In managing the field of financial stability support, it also turned towards more social and growth-friendly policies. Again, the incoming Juncker Commission intensified these efforts. Juncker's efforts in brokering a deal for a third Greek bailout in the spring of 2015 incensed the German and like-minded governments. His ostensible sympathy for Greek demands led the German Finance Minister, Wolfgang Schäuble, to publicly reflect on curtailing the powers of the Commission by separating its political leadership from some administrative functions (Mussler 2015). These examples show that the Commission is both willing and able to influence EU policy-making in economic governance. To this end, it is not any longer fully dependent hard law proposals, but increasingly competent to pursue its agenda through the various management functions it has gathered during the crisis. By linking its outputs in the various monitoring and coordination procedures, it can provide quite some impetus in economic governance.

\section{Conclusion: A new kind of engine?}

Although the Eurozone crisis severely tested the Commission, it was only the latest challenge for an institution that has been embattled since the Maastricht Treaty and arguably before. The Commission has been repeatedly challenged by empowered institutions, i.e., the European Council and the European Parliament, and since the 1990s has been constrained by a political climate that has been increasingly hostile to action on the part of 'Brussels'. Yet the crisis did not change the Commission. Rather, it acted as a catalyst for a process of transformation that was already underway. On taking office in 2004, Barroso argued for a more presidential Commission that would take a more measured, strategic and responsive approach to policy. The crisis strengthened his hand, leading him to limit Commission action to those areas of policy that required urgent action - economic and monetary policy, financial services, competition policy, and trade.

Although the Commission is under pressure, it is not facing general decline. Rather, its approach and outlook has changed. A new more restrained model has emerged, with the ex- 
pansionist and interventionist ways of the past firmly set aside. Policy entrepreneurship in the classic sense - i.e., formulating and pushing for hard law - may be increasingly difficult in the current EU, but the Commission can succeed if its efforts are strategic and focused. Moreover, its array of management duties ensures that it is able to exert influence on EU action in less intrusive ways. At the same time, the crisis accelerated the process of presidentialisation within the Commission, leaving the President with new powers and resources to take personal control over the policy agenda. In combination, increased management responsibilities and strong presidentialism allowed the Commission to be assertive in the crisis context. The lesson from the crisis years is therefore that, at least in economic governance, the Commission is still able to act as an engine of integration; yet it is an engine increasingly different from the traditional understanding.

It remains to be seen whether this transformation will take the same form and have the same effect in other areas. As the Commission's competences vary across policy areas, different sectoral modes of entrepreneurialism may emerge. Given the trend of presidentialisation, and along with it prioritisation, some policy areas will receive even less attention in the near future - a tendency evident in interviews with some outgoing Commissioners in 2014, who expressed disappointment that items from their portfolios rarely featured on the Commission's agenda. The Commission will not be able or willing to advance integration in all fields at all times or at the same pace.

Yet, although the Commission has been remodelled, it is not clear that it has been 'recast' 'in a new mould' (Bickerton et al. 2015b: 39) as suggested by the new intergovernmentalism. The argument that it is by now more circumspect about pursuing an ever closer union cannot be dismissed. Neither can the claim that supranational institutions act strategically depending on the level of support in the political environment. But the assertion that the Commission has abandoned any pretentions to leadership or any policy ambitions appears to be unwarranted. Not only has the Commission emerged from the Eurozone crisis with expanded management functions, as Puetter (2015) has acknowledged, which it can and does use to provide less intrusive impetus for policy-making; classic Commission policy entrepreneurship also remains, as initiatives in the area of economic governance and beyond (financial services, energy, the environment and migration) make clear.

The changing institutional balance since the Lisbon Treaty and the Eurozone crisis, in particular in the field of leadership, may go beyond the traditional dichotomy of integration theory. Crespy and Menz (2015: 765) have, for instance, argued that a 'new hybrid form of 
governance drawing from both political intergovernmentalism and technocratic supranationalism' has emerged in the wake of the latter. The role of the Commission appears to be a prime example. Far-reaching entrepreneurship has diminished to a large extent but many of the new technical duties in budgetary and macroeconomic monitoring, have a strong political component, with leadership implications. The Commission has also shown historically that it can act as a 'purposeful opportunist' (Cram 1994: 214), employing various techniques beyond the proposal of hard law to eventually further integration. Now that it is more hierarchical in its internal organization, the strategic use of different methods to realize this goal is even more feasible. The Commission's role as an engine of integration will therefore endure, but in a different guise.

\footnotetext{
Notes

${ }^{1}$ The surveys and interviews were conducted as part of two research projects. The first project ('The European Commission in Question', 2008-2009) comprised an online survey in the Commission ( $\mathrm{n}=1901)$ and interviews with Commissioners $(\mathrm{n}=5)$, cabinet members (28) and managers $(\mathrm{n}=119)$. It was led by Hussein Kassim (PI) and John Peterson, involved Michael W. Bauer, Sara Connolly, Renaud Dehousse, and Liesbet Hooghe, and was funded by the UK Economic and Social Research Council (grant no. RES-062-23-1188). For more information, see http://www.uea.ac.uk/psi/research/EUCIQ. The findings are presented in Kassim et al. 2013. The second project ('European Commission: Facing the Future', 2014) included an online survey $(\mathrm{n}=5,545)$ and interviews with Commissioners $(\mathrm{n}=9)$, cabinet members $(\mathrm{n}=25)$, and managers $(\mathrm{n}=120)$, conducted between March and September 2014. The project was led by Kassim and Connolly, the research team included Michael W. Bauer, Renaud Dehousse, and Andrew Thompson.

${ }^{2}$ There are 'indirect' rights of initiative for the Parliament (Art. 225 TFEU), the Council (Art. 241 TFEU) and even the citizens via the European Citizens Initiative (Art. 11(4) TEU), who all can 'invite' the Commission to submit a legislative proposal. The Lisbon Treaty strengthened the Parliament's indirect right by codifying the obligation of the Commission to give reasons when not submitting a proposal following an invitation.

${ }^{3}$ Some of these differences reflect cross-sectoral variation in the development of the acquis communautaire. In some areas, the regulatory regime was already mature. In others, EU legislative action was newer or had been less extensive.

${ }^{4}$ There is some debate to what extent the Commission can generally be considered a winner of the Eurocrisis (da Conceição-Heldt 2016; Bauer and Becker 2016); however, there is agreement that in the field of macroeconomic and budgetary surveillance, this verdict does hold true.

${ }^{5}$ Interview conducted by Hussein Kassim and Renaud Dehousse, Brussels, 6 May 2015.

${ }^{6}$ Interview with cabinet member of Commission President Juncker, conducted by Hussein Kassim, 18 June 2015

${ }^{7}$ There are important exceptions. One example is Neil Kinnock, who led administrative reform in the Prodi Commission.

${ }^{8}$ Interview with cabinet member of former Commission President Barroso, conducted by Sara Connolly and Hussein Kassim, 5 May 2015.
} 


\section{References}

Bauer, Michael W. (2006). 'Co-managing Programme Implementation: Conceptualizing the European Commission's Role in Policy Execution', Journal of European Public Policy, 13:5, 717-735.

Bauer, Michael W., and Stefan Becker (2016). 'Absolute Gains Are Still Gains: Why the European Commission Is a Winner of the Crisis, and Unexpectedly So. A Rejoinder to Eugénia da Conceição-Heldt', Journal of European Integration, 38:1, 101-106.

Bauer, Michael W., and Stefan Becker (2014). 'The Unexpected Winner of the Crisis: The European Commission's Strengthened Role in Economic Governance', Journal of European Integration, 36:3, 213-229.

Bickerton, Christopher J., Dermot Hodson, and Uwe Puetter (2015a). 'The New Intergovernmentalism: European Integration in the Post-Maastricht Era', JCMS: Journal of Common Market Studies, 53:4, 703-722.

Bickerton, Christopher J., Dermot Hodson, and Uwe Puetter (2015b). 'The New Intergovernmentalism and the Study of European Integration', in Bickerton, Christopher J., Dermot Hodson, and Uwe Puetter (eds.), The New Intergovernmentalism: States and Supranational Actors in the Post-Maastricht Era. Oxford: Oxford University Press, 148 .

Campbell, John (1983) Roy Jenkins: A Biography. London: Weidenfeld and Nicolson.

Christiansen, Thomas (2016). 'The Spitzenkandidaten process...', West European Politics, this Issue, $\mathrm{XXX}-\mathrm{XXX}$.

Copeland, Paul, and Scott James (2014). 'Policy Windows, Ambiguity and Commission Entrepreneurship: Explaining the Relaunch of the European Union's Economic Reform Agenda', Journal of European Public Policy, 21:1, 1-19.

Cram, Laura (1994). 'The European Commission as a Multi-organization: Social Policy and IT Policy in the EU', Journal of European Public Policy, 1:2, 195-217.

Crespy, Amandine, and Georg Menz (2015). 'Commission Entrepreneurship and the Debasing of Social Europe Before and After the Eurocrisis', JCMS: Journal of Common Market Studies, 53:4, 753-768.

da Conceição-Heldt, Eugénia (2016). 'Why the European Commission is not the "unexpected winner" of the Euro Crisis: A Comment on Bauer and Becker'. Journal of European Integration, 38: 1, 95-100.

Dehousse, Renaud (2015). 'The New Supranationalism'. Paper presented at the 22nd Annual Conference of the Council for European Studies, Paris, 8-10 July 2015.

Dimitrakopoulos, Dionyssis G. 2008. 'Collective Leadership in Leaderless Europe: A Sceptical View', inHayward, Jack E.S. (ed.), Leaderless Europe. Oxford: Oxford University Press, 288-303.

European Commission (2015). Commission Work Programme 2015. COM/2014/0910 final.

European Commission (2014a). 40 Years Eurobarometer.

European Commission (2014b). 'The Juncker Commission: A strong and experienced team standing for change', Press Release, IP/14/984, 10 September 2014.

European Commission (2013). Standard Eurobarometer 80. 
Fabbrini, Sergio (2013). 'Intergovernmentalism and Its Limits. Assessing the European Union's Answer to the Euro Crisis', Comparative Political Studies, 46:9, 1003-1029.

Haas, Ernst B. (1958). The Uniting of Europe. Political, Social, and Economic Forces: 19501957. Stanford: Stanford University Press.

Hodson, Dermot (2013). 'The Little Engine that Wouldn't: Supranational Entrepreneurship and the Barroso Commission', Journal of European Integration, 35:3, 301-314.

Hooghe, Liesbet, and Gary Marks (2008). 'A Postfunctionalist Theory of European Integration: From Permissive Consensus to Constraining Dissensus', British Journal of Political Science, 39:1, 1-23.

Hutter, Swen, \& Grande, Edgar (2014). 'Politicizing Europe in the National Electoral Arena: A Comparative Analysis of Five West European Countries, 1970-2010', JCMS: Journal of Common Market Studies, 52:5, 1002-1018.

Juncker, Jean-Claude (2014). 'Time for Action - Statement in the European Parliament Plenary Session ahead of the Vote on the College', available at: http://europa.eu/rapid/pressrelease_SPEECH-14-1525_en.htm (accessed 17 August 2015).

Kassim, Hussein (2008). “Mission Impossible”, But Mission Accomplished: The Kinnock Reforms and the European Commission', Journal of European Public Policy, 15:5, 648-668.

Kassim, H., and Anand Menon (2010) 'Bringing the Member States Back in: The Supranational Orthodoxy, Member State Resurgence and the Decline of the European Commission since the 1990s', paper presented at ECPR Fifth Pan-European Conference in Porto, Portugal, 23-26 June.

Kassim, Hussein, and Anand Menon (2004). 'EU Member States and the Prodi Commission' in Dionyssis G. Dimitrakopoulos (ed.), The Changing European Commission. Manchester: Manchester University Press, 89-104.

Kassim, Hussein, Sara Connolly, Renaud Dehousse, Olivier Rozenberg, and Selma Bendjaballah (2016). 'Managing the House: The Presidency, Agenda Control and Policy Activism in the European Commission', forthcoming.

Kassim, Hussein (2012). 'The Presidents and Presidency of the European Commission'. in Erik Jones, Anand Menon, and Stephen Weatherill (eds.), The Oxford Handbook of the European Union. Oxford: Oxford University Press, 219-232.

Kassim, Hussein, John Peterson, Michael W. Bauer, Sara Connolly; Renaud Dehousse, Liesbet Hooghe, and Andrew Thompson (2013). The European Commission of the Twenty-First Century. Oxford: Oxford University Press.

Kurpas, Sebastian, Caroline Grøn, and Piotr Maciej Kaczynski (2008). The European Commission after Enlargement: Does More add up to Less? Brussels: Centre for European Policy Studies.

Laffan, Brigid (2016). 'Europe's Union in Crisis -Tested and Contested', West Europea Politics, this SI, XXX-XXX.

Laffan, Brigid (1997). 'From policy entrepreneur to policy manager: the challenge facing the European Commission', Journal of European Public Policy, 4:3, 422-438.

Lindberg, Leon N. (1965). 'Decision Making and Integration in the European Community', International Organization, 19:1), 56-80. 
Metcalfe, Les (1992). 'After 1992: Can the Commission Manage Europe?', Australian Journal of Public Administration, 51:1, 117-130.

Moravcsik, Andrew (1999). 'A New Statecraft? Supranational Entrepreneurs and International Cooperation', International Organization, 53:2, 267-306.

Mussler, Werner (2015). 'Schäuble will EU-Kommission entmachten', Frankfurter Allgemeine Zeitung, 29 July 2015.

Pelkmans, Jacques (2016). 'Why the Single Market Remains EU's Core Business', West European Politics, this SI, XXX-XXX.

Peterson, John (2015). 'The Commission and the New Intergovernmentalism: Calm within the Storm?', in Christopher J. Bickerton, Dermot Hodson, and Uwe Puetter (eds.), The New Intergovernmentalism. Oxford: Oxford University Press, 185-207.

Puetter, Uwe (2015) 'Deliberativer Intergouvernementalismus und institutioneller Wandel: die Europäische Union nach der Eurokrise', Politische Vierteljahreszeitschrift, 56:3, 406-531.

Puetter, Uwe (2012). 'Europe's Deliberative Intergovernmentalism: The Role of the Council and European Council in EU Economic Governance', Journal of European Public Policy, 19:2, 161-178.

Schmidt, Vivien A. (2016). 'Reinterpreting the Rules 'by Stealth' in Times of Crisis: The European Central Bank and the European Commission, West European Politics, this SI, XXX-XXX. 